\title{
Calcined Kiln Analysis and Proximate Simulation of High-Quality Coke Products Using Aspen Plus
}

\author{
Atika Safitri ${ }^{1 *}$, Ghiyar Ragil Alfath ${ }^{1}$, Wara Dyah Pita Rengga ${ }^{1}$, Nugroho Adi Sa- \\ songko ${ }^{2}$, Immanuella Juan Safira ${ }^{1}$
}

\author{
${ }^{1}$ Chemical Engineering Department, Universitas Negeri Semarang, Indonesia \\ ${ }^{2}$ Agency for the Assessment and Application of Technology, Indonesia \\ ${ }^{*}$ Corresponding author. Email: atika05@students.unnes.ac.id
}

\begin{abstract}
Indonesia's green petroleum coke production capacity reaches 360,000 tons/year. Green Petroleum Coke (GPC) is the most widely used raw material in the manufacture of anodes for aluminium and steel smelters, but it is does not have good quality for smelting because it contains high ash, volatile matter and carbon. It is necessary to produce $\mathrm{CPC}$ that meets industry standards. Calcined Petroleum Coke (CPC) is produced from calcined coke technology by heating coke to a high temperature of $550-1,150{ }^{\circ} \mathrm{C}$ using a rotary kiln or vertical shaft kiln. The calcination process mostly determines the characteristic quality of the petroleum coke produced. This study will compare the advantages of product characteristics resulting from calcination technology between rotary kilns and shaft kilns and analysed calcined coke using Aspen Plus to produce high quality coke products that meet industry demand parameter standards; sulphur content (0.5-1.5\%), fixed carbon (99.3\%), volatile matter $(0.5 \%)$ and ash $(0.5 \%)$ and reduction of wasted $\mathrm{CO} 2$ gas emissions. thus can support the mining industry. Mining down streaming also encourages the country's foreign exchange savings and boosts the domestic economy. Thus, Indonesia can produce economical steel and smelters.
\end{abstract}

Keywords: coke, kiln, mining, ash, smelter

\section{INTRODUCTION}

High quality coke product is used to fulfill the smelting process of aluminum, magnesium, and steel, which almost of activities in the metallurgical sector certainly require a smelting process. Calcined Petroleum Coke (CPC) is required as a quality standard for graphite electrode and anode paste products [1], needle-grade [2], $\mathrm{TiO}_{2}$ pigments [3]. The current use of CPC is for the aluminum $(70 \%)[4]$, titanium dioxide $(10 \%)$ industry as well as the foundry [5], steel and electrode industries [6]. $\mathrm{CPC}$ is also required in in the food grade phosphate [7] and the calcium carbide industry [8]. Problems caused by increasing the amount of steel and scrap metal [9] can be reduced by re-smelting. The existence of calciners used in developing countries that have abundant amounts of green petroleum coke still uses rotary kilns. Rotary kiln technology has become a fairly good technology in making CPC. Judging from the calcination temperature carried out in a rotary kiln, usually around $1400^{\circ} \mathrm{C}$ [10], it is possible to increase the quality of coke by eliminating volatility by reducing the hydrogen content, so that the coke will have high temperature strength and heat resistance and to increase the conductivity of the graphite electrode [6].

The raw materials that affect the quality of the anode in the synthesis are CPC, Coal Tar Pitch (CTP), and butt anode [11]. Green Petroleum Coke (GPC) is not widely used because it does not have a good hardness as a casting tool [12]. Taking into account the quality of CPC produced from foreign products, it is necessary to manufacture CPC that has characteristics in accordance with industry standards. Chemical criteria can be found in sulphur content (maximum 1\%), fixed carbon (minimum $98.5 \%)$, volatile matter $(0.5 \%)$ and ash $(0.5 \%)$ in the manufacture of CPC.

Considering that calcination can be carried out on rotary kilns and vertical shaft kilns, it is necessary to find the weaknesses and strengths of the CPC products produced 
by comparing the results of the work of the two types of kilns. This study aims to compare the physical and chemical characteristics of calcined coke in Rotary Kiln and Vertical Shaft Kiln Technology. The purpose of the study was to compare the types of Rotary Kiln and Vertical Shaft Kiln Technology and process simulations calcinated coke using Aspen Plus to produce high quality petroleum coke from delayed coke with high ash.

\section{METHODS}

\subsection{The Sample Preparation}

The sample preparation consisted of the five main production steps; identification, grinding, mixing, forming, and baking. Figure 1 presents a complete flowchart of the making anode process. GPC must be identified first by proximate and ultimate analysis to determine the magnitude of the value of the GPC content. After obtaining proximate and ultimate analysis data, GPC was calcined by a furnace at $900-1300^{\circ} \mathrm{C}$ for $1-3 \mathrm{~h}$. Variations in temperature and time of baking coke in the furnace are used to determine the physical properties of coke. Air permeability and reactivity are both increased by microporosity. When carbon anodes contact air, air reactivity becomes an issue because air burn causes excessive anode consumption [13]. Crude coke that has undergone calcination was tested for sulphur content and Grain Hardness Index that meets the quality as raw material for anode production.

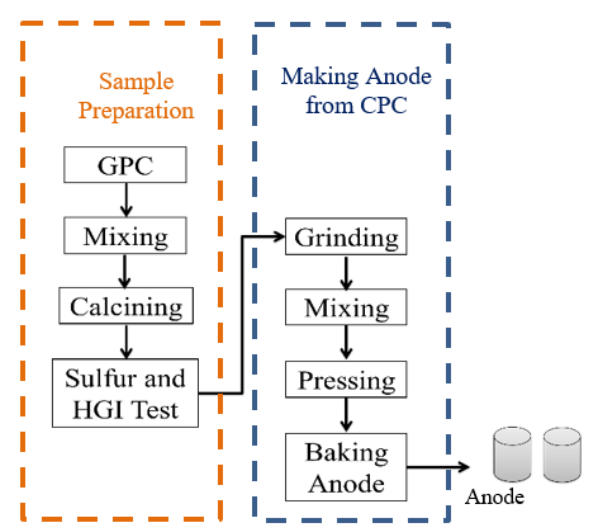

Figure 1. The flowchart of the making anode from calcined Petroleum Coke

Materials consisting of CPC, Coal Tar Pitch (CTP), and butt are fed into a ball mill for the grinding process until it reaches eight mesh. The grinding process is to make homogeneous the surface area. Selection of the proper mixing temperature in perfect melting requires a temperature higher than the melting point for the mixture of coke, pitch, and butt materials by increasing the temperature to more than $50^{\circ} \mathrm{C}$ [14]. The finished material is then forming and pressing into briquettes using a cylindrical mold $\left(785 \mathrm{~cm}^{2}\right)$ that is squeezed at $200 \mathrm{~kg} / \mathrm{cm}^{2}$. The baking anode process for industrial scale, on average it takes two weeks [13].

\subsection{The Properties of Green Petroleum Coke (GPC)}

Green Petroleum Coke (GPC) is a material with high carbon content. The coking used the raw materials obtained from primary and secondary oil refining. As a result, GPC has a lower economic value than gas, oil, and top refinery products, around 2-3\% [4]. GPC has three different types of structures, including needle coke, sponge coke, and shot coke. The shot coke has a finegrained texture and identical characteristics in full directions with a layered structure and a coarser texture [15]. This type of coke is commonly used in the aluminum industry. In contrast, needle coke is generally used in the steel industry because it contains low sulfur and a low coefficient of thermal expansion. Finally, the sponge coke has a heterogeneous structure with a combination of fine and coarse textures [16].

The quality of petroleum coke is determined by the composition of the raw materials. Asphaltenes which are high in raw materials will contain more sulfur and metals than coke which is produced from high aromatic raw materials. The sulfur content of petroleum coke reaches $0.5 \%$ to $10 \%$ as organic sulfur. The applications of GPC are, 1) fuel (mixed with coal) in cement plants, metal smelters, power plants, 2) reductant in the tin smelting process, and 3) raw material for the manufacture of calcined coke, which is used as an ingredient in the decomposition process between alumina slurry and other materials. Table 1 contains the Indonesian GPC, which belongs to the type of sponge cake. Sponge coke is the best type if further processed to produce calcined Petroleum Coke (CPC) because of its lower sulphur content and high porosity. In addition, the open porosity of sponge coke allows for good pitch penetration during mixing that makes a mechanically robust interlocking structure form after anode baking [4].

\subsubsection{The Calcined Coke Technology}

Calcination is a heat treatment process that involves heating GPC to a specific temperature up to $1200-1400^{\circ} \mathrm{C}$. Calcination results affect moisture removal, driving volatile matter and producing anode with the highest purity. The material also has physical strength and electrical conductivity with the most negligible porosity and reactivity [8] because of the impact of calcinating. Calcining 
the GPC is heating to remove the volatile content to reduce the hydrogen concentration and increase graphitization. Increasing graphitization improves the GPC's resistance to high temperatures and increases the graphite electrode's conductivity. Table 1 shows a comparison of the features of GPC and CPC [17].

Table 1. The physical properties of GPC and CPC

\begin{tabular}{|l|c|c|}
\hline \multirow{2}{*}{ Parameter } & \multicolumn{2}{c|}{ Petroleum Coke } \\
\cline { 2 - 3 } & Green & Calcined \\
\hline $\begin{array}{l}\text { Ash (including } \\
\text { heavy metals: Ni, V) }\end{array}$ & $0.19-0.35$ & 0.35 \\
\hline Volatile Matter & $9-14$ & $<0.25$ \\
\hline Carbon & $89.58-91.80$ & 98.40 \\
\hline Sulfur & $1.29-3.42$ & 1.20 \\
\hline Hydrogen & $3.71-5.04$ & 0.14 \\
\hline Nitrogen & $0.95-1.20$ & 0.22 \\
\hline Oxygen & $1.30-2.14$ & 0.02 \\
\hline
\end{tabular}

These properties can be analysed during the CPC manufacturing process, there are some fixed and changing properties. The fixed data and must be prepared to get CPC according to the standard is an ash. Ash is a nonvolatile inorganic mineral compound and tends to follow as coke. A strategy is needed at the beginning to get maximum $0.5 \%$ ash on the GPC composition. The amount of $\%$ mass that is decreasing is volatile matter, sulphur and gas $\mathrm{N}_{2}, \mathrm{O}_{2}$ and $\mathrm{H}_{2}$ which is different from the amount of fixed carbon which is certain to increase, because the desired target is to get the highest amount of fixed carbon and hopefully without impurity.

Several types of technology are commonly used in the coke calcination process, namely rotary kiln and vertical shaft kiln. Rotary kilns are widely used worldwide, especially in Europe, while vertical shaft kilns are commonly used in China. In addition to the excellent quality of calcined petroleum coke (CPC), technology with operating conditions and energy requirements is more efficient in selecting calcination technology. In contrast, the experiments in the furnace were carried out to determine the optimal time and temperature used for GPC combustion to produce CPC with good quality. Both are interrelated in assessing the quality of GPC and CPC to be processed. The optimal roasting temperature will vary depending on the quality of the coke and the sulphur content at the time of production.

\subsubsection{Rotary Kiln Technology.}

A rotary kiln is a furnace generally built as a cylinder that rotates $60 \mathrm{~m}$ long, 2-3 $\mathrm{m}$ in diameter, and turns 2 - 4 rpm [8]. The rotary kiln has a tremendous capacity and a swift residence time. In a rotary kiln, sufficient heat is supplied to raise the temperature of the CPC to the desired level for efficient mixing of the process resulting in uniform heat transfer [7]. The ability of rotary kilns to work with a more extensive volatile matter range (VM) of GPC is forgiving. However, the higher VM cokes will have a more significant negative impact on coke bulk density. It can make the coke layer build-up on the inside of the refractory layer at the feed end of the kiln. Hence, the effective diameter of the kiln and can even reduce production rates [18].

The GPC is fed to the bottom of the kiln opposite the hot combustion gases in the calcination process. The temperature increase is reached at about 13 to $20 \mathrm{~m}$ before the kiln exhaust end. The first zone of the kiln is called the Heat-Up Zone. The water vapor released from the coke structure at temperatures between $25-400{ }^{\circ} \mathrm{C}$ and $400-1000{ }^{\circ} \mathrm{C}$ is the Devolatilization zone. Heating at high temperatures results in the release of many compounds, especially the reduction of hydrogen released into the air. In addition, sulfur compounds are also reduced and released into the air but cause harmful gases. The remaining material is in the form of solids that still survive at high temperatures. The volatile material and the liquid phase then release into gas. The remaining coke is known as densification (shrinkage of coke construction). These reactions are incorporated in the Calcined Coke Zone, which degrades from 1000 to $1400{ }^{\circ} \mathrm{C}$ at the end of the kiln. [19].

\subsubsection{Vertical Shaft Kiln Technology}

The vertical shaft kiln used the principle of gravity. GPC is injected at the top kiln then moves down and out through a cold water jacket at the bottom. The disadvantage of this shaft kiln is the long residence time because the heating rate is only $\sim 1^{\circ} \mathrm{C} / \mathrm{min}$ [8]. On the other hand, a long heating rate can produce better quality output than a rotary kiln because the heating is higher and stable. In addition, the size of the coke feed that is fed into the kiln is not too tight.

The vertical shaft kiln is heated indirectly on both sides by baffled combustion. Preheating zone is used to remove moisture and volatiles. Between $500^{\circ} \mathrm{C}-1,000^{\circ} \mathrm{C}$, a devolatization process occurs in which some volatiles condense inside the kiln of the colder cokes granular. Calcination xone is occurs at $1,250-1,380^{\circ} \mathrm{C}$. At the Calcination Zone's end, further coke shrinkage (densification) appears at the flue's maximum temperature reaches $1,250-1,380^{\circ} \mathrm{C}$. 
Table 2. Comparison process parameters of technology rotary kiln and vertical shaft kiln

\begin{tabular}{|c|c|c|}
\hline Properties & Rotary Kiln & Vertical Shaft Kiln \\
\hline Sizing $(\%)>4 \mathrm{~mm},>1 \mathrm{~mm},<0.25 \mathrm{~mm}$ & $30-45,60-75,5-10$ & $45-70,75-85,2-5$ \\
\hline $\begin{array}{l}\text { Bulk density }\left(\mathrm{kg} / \mathrm{dm}^{3}\right) 8-4 \mathrm{~mm}, 2- \\
1 \mathrm{~mm}, 1-0.5 \mathrm{~mm}, 0.5-0.25 \mathrm{~mm}\end{array}$ & $\begin{array}{l}0.62-0.70,0.78-0.86 \\
0.83-0.92,0.86-0.93\end{array}$ & $\begin{array}{l}0.64-0.70,0.76-0.89 \\
0.82-0.89,0.85-0.90\end{array}$ \\
\hline Grain stability (\%) & $70-85$ & $75-90$ \\
\hline Density in xylene $\left(\mathrm{kg} / \mathrm{dm}^{3}\right)$ & $2.05-2.10$ & $2.08-2.12$ \\
\hline Crystallite size $(\AA)$ & $25-32$ & $28-35$ \\
\hline Spec.electr. resistance $(\mu \Omega m)$ & $460-560$ & $380-500$ \\
\hline Maximal grain motion $(\mathrm{m} / \mathrm{h})$ & 1000 & 0.3 \\
\hline Residence time (heat up rate) & $1 \mathrm{~h}\left(50-100^{\circ} \mathrm{C} / \mathrm{min}\right)$ & $18-20 \mathrm{~h}\left(1-2^{\circ} \mathrm{C} / \mathrm{min}\right)$ \\
\hline Downtime per year & $1 \mathrm{~h}\left(50-100^{\circ} \mathrm{C} / \mathrm{min}\right)$ & $18-20 \mathrm{~h}\left(1-2^{\circ} \mathrm{C} / \mathrm{min}\right)$ \\
\hline Downtime per year & 1-3 Months & None in 8 Years \\
\hline Cooling down duration & 3-4 Days & 2-3 Months \\
\hline The adaptability of volatile matter (\%) & $9-11$ & $9-15$ \\
\hline Maximal coke temperature $\left({ }^{\circ} \mathrm{C}\right)$ & 1250 & $1350^{\circ} \mathrm{C}$ \\
\hline $\mathrm{CO}_{2}$ emission $\left(\mathrm{tCO}_{2} / \mathrm{tCPC}\right)$ & 0.6 & 1.0 \\
\hline Combustion loss & VM \& Coke (10\%) & VM \& Coke $<4 \%$ \\
\hline Ylied: dryfeed calcined (\%) & 75 & 85 \\
\hline CAPEX,US\$/ton CPC & $500-750$ & $300-500$ in China \\
\hline OPEX, US\$/ton CPC & $60-96$ & $45-75$ \\
\hline
\end{tabular}

\section{RESULTS AND DISCUSSION}

\subsection{Comparison of Rotary Kiln and Vertical Shaft Kiln Technology}

The petroleum coke is calcined at the top of the vertical shaft kiln which is injected with air, and the steam is injected into the bottom of the kiln. Reaction with hot coke below the combustion zone to produce hydrogen and carbon monoxide. A hydrogen-rich, lownitrogen-rich product gas stream is drawn from the level below the combustion zone in the kiln. High sulfur coke can be desulfurized in the process by maintaining the temperature in the calcination zone. In a vertical kiln, an elongated combustion chamber has a channel for injecting gaseous fuel into the lower center zone. The drain hole is positioned in such a way that its contents will automatically exit by gravity through the hole into the space at its upper end and keep the chamber filled at a constant rate of material. Both kilns can be used to produce CPC from GPC.

Differences in the advantages and disadvantages of each calcination technology segment. The coke calcination technology was developed to produce CPC with good quality and economic efficiency. The data. An analysis of the data presented in Table 2 regarding the comparison of properties of rotary and shaft type kiln technology, the physical properties of the shaft are more uniform in size, the size range is narrower than the rotary kiln product. Grain stability and yield in both wet and dry forms are superior to shaft kilns.

The temperature achieved during the manufacture of $\mathrm{CPC}$ is quite high for the shaft kiln at $1350^{\circ} \mathrm{C}$, but the emissions produced are also quite high with a difference of $40 \%$ from the rotary kiln system which has cleaner exhaust energy. This comparison informs that if the manufacture of GPC into CPC uses a shaft kiln, the most chosen of the overall properties and indicators is the yield (see Table 3).

According from Tabel 3, the analysis of the proximate test results on GPC products from petroleum factories in Indonesia shows that the moisture and ash levels are still too high from the CPC industrial specification, while the appropriate sulfur value is less than $1 \%$. The results of the analysis of the GPC I calcined (ie CPC I) showed a decrease in the moisture content but the ash content was still high reaching $3 \%$ which should be $0.25 \%$. Even though the quality of the CPC obtained must be in accordance with industry standards, then the GPC needs to be modified with CPC containing smaller 
ash, that is 0.03 (from the proximate analysis of CPC merk Y). Anode manufacture requires a composition of a high sulphur content. Higher SO2 emissions can be avoided by mixing low sulfur coke into the coke

Table 3. Modify high ash GPC to get CPC.

\begin{tabular}{|l|c|c|c|c|c|}
\hline Components & GPC & CPC Y & CPC I & Change & Standard Methods \\
\hline Moisture & 0.62 & 9.7 & 0.5 & -0.12 & ASTM D3173 \\
\hline Ash & 3.24 & 0.12 & 0.5 & -2.74 & ASTM D3174 \\
\hline Volatile matter & 16.14 & 13.4 & 0.5 & -15.64 & ASTM D3175 \\
\hline Fixed carbon & 80.00 & 86.3 & 98.5 & +18.5 & ASTM D3172 \\
\hline Sulphur & 0.56 & 0.64 & 1.0 & & ASTM D4239 \\
\hline
\end{tabular}

$60 \%$ of GPC, $16 \%$ and $24 \%$ of butt. The material is molded into blocks and baked in a separate anode furnace at a temperature of about $1200^{\circ} \mathrm{C}$. The aluminum and iron rods are then cast or rammed into grooves at the top of the anode block to support the anode and conduct electric current to the anode when it is positioned in the cell.

The condition of GPC which is still high in ash content cannot reach the desired CPC specifications. The analysis of the GPC modification was carried out by adding other product CPC where the local CPC content was still not based on the proximate and ultimate test results, $60 \%$ GPC could use $30 \%$ Indonesian local coke mixed with $30 \%$ Oxbow coke (see table 4). Meanwhile, CTP can use $12 \%$ refined tar upgrading from the Indonesian steel industry and 4\% CTP from Anyang or Himadri. This formula is used to produce anodes that comply with industry standards, so that GPC Indonesia can be utilized and processed into something of high value.

In a previous study conducted by Indonesia regarding the calcination of GPC into CPC as raw material for anode smelters using a rotary kiln at a temperature of $1280^{\circ} \mathrm{C}$. After doing proximate analysis, the results of CPC with fixed carbon content reached 99.25 , but the high ash content was 92.5 . Referring to these results, this research was carried out by calcining at a temperature of $900-1100^{\circ} \mathrm{C}$ to produce CPC with low ash content. In addition to the fixed carbon and ash targets, the expected CPC must also contain a high sulphur value, in order to achieve a high sulphur value, the anode manufacturing process requires a mixture of calcined local coke that has aggregate or removing sulfur by increasing the calcination temperature of the coke and increasing the residence time in the coke. However, this will result in higher coke unsuitable for anode preparation due to the decrease in bulk density caused by increased sulfur content [6].

For baking, anode technology is divide into two types, open and closed type furnace design. The open type furnace is horizontal throughout flue wall baffle indirectly only sidely with energy consumption less than $2.3 \mathrm{GJ} / \mathrm{TBA}$ and emission level $-100-300 \mathrm{mg} / \mathrm{Nm}^{3}$. Meanwhile, the close type furnace is vertical throughout the flue wall channels indirectly; sidely, from top and bottom with consumption energy is $\leq 2.2 \mathrm{GJ} / \mathrm{TBA}$. Moreover, have an emission level of -800 to 1000 $\mathrm{mg} / \mathrm{Nm}^{3}$ [22].

\subsection{Description Models}

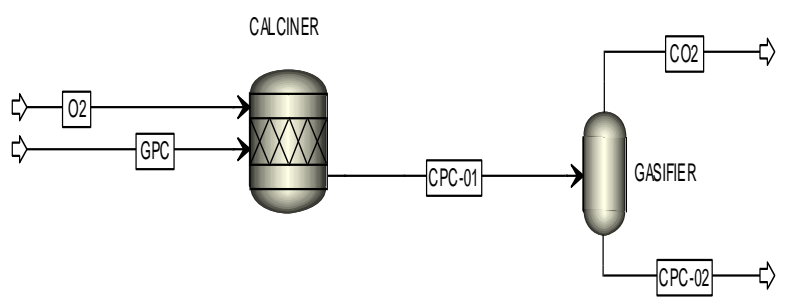

Figure 2. Simulation process for calcining coke

Table 4. The proximate and ultimate analysis of several coke.

\begin{tabular}{|l|c|c|c|c|}
\hline \multicolumn{1}{|c|}{ Components } & GPC (\%) & OXBOW (\%) & YOSOMULYO (\%) & Standard Methods \\
\hline Moisture & 0.62 & 0.06 & 0.18 & ASTM D3173 \\
\hline Ash & 3.24 & 2.46 & 0.03 & ASTM D3174 \\
\hline Volatile matter & 16.14 & 0.76 & 16.70 & ASTM D3175 \\
\hline Fixed carbon & 80.00 & 96.72 & 83.09 & ASTM D3172 \\
\hline Sulfur & 0.56 & 3.05 & 0.74 & ASTM D4239 \\
\hline
\end{tabular}


The manufacture of anodes with GPC raw materials indeed produces pollution. The combustion environment in the calciner is the primary method to control the formation of pollutant gases.

Figure 2 is a calciner process model in Aspen Software Simulation based on the combustion mechanism analysis. Process simulation studies of actual industrial processes can identify the calcination technology and substantially improve process and facility parameters and pollutant screening emission reductions.

The method using Peng-Robinson equation of state with modifications was used for thermodynamic properties. The Peng-Robinson method is the global property method to compute the thermodynamic properties of every stream [23]. The calciner and gasifier are represented as equilibrium reactors, with the equilibrium defined by the Gibbs free energy reactor [24]. The temperature and pressure in the calciner is $1100^{\circ} \mathrm{C}$ and 20 atm and assumed to be adiabatic. While the temperature and pressure for the gasifier is $1100^{\circ} \mathrm{C}$ and $20 \mathrm{~atm}$. The solid product of the calciner is dry coke (CPC). After establishing each block's operating settings and the state parameters of individual material and heat streams, software analysis determines each unit operation block's material and energy balance in the sequence chosen by the user. The conditions of the major material streams are summarized in Tabel 5. Then confirming its correctness by comparing the model's estimated outputs with actual industrial data, the model may be used to replicate actual industries [23].

Table 5. The proximate and ultimate analysis using software simulation

\begin{tabular}{|l|c|c|c|}
\hline \multicolumn{1}{|c|}{ Analysis } & $\begin{array}{c}\text { GPC } \\
(\%)\end{array}$ & $\begin{array}{c}\text { CPC-01 } \\
(\%)\end{array}$ & $\begin{array}{c}\text { Change } \\
(\%)\end{array}$ \\
\hline \multicolumn{4}{|c|}{ Proximate Analysis } \\
\hline Moisture & 0.62 & 0.4 & -0.22 \\
\hline Ash & 3.24 & 0.25 & -2.99 \\
\hline Volatile matter & 16.14 & 0.45 & -15.69 \\
\hline Fixed carbon & 80.00 & 99.3 & +19.3 \\
\hline Ultimate Analysis \\
\hline Carbon & 84,86 & 84,86 & \\
\hline Hydrogen & 3,74 & 3,74 & \\
\hline Nitrogen & 1,39 & 1,39 & \\
\hline Oxygen & 6,21 & 6,21 & \\
\hline Sulphur & 0.56 & 0.56 & \\
\hline
\end{tabular}

Fring petroleum coke would be more efficient than firing natural gas. Using the natural gas, the gas product from the calciner contains more $\mathrm{H}_{2} \mathrm{O}$, which lowers the purity of the $\mathrm{CO}_{2}$ stream. This also suggests that it is advantageous to use petroleum coke for calcination. [25]. Many factors can be influence the flue gas components, as the physical and chemical properties of fuels and raw materials, operating conditions, flow rates of the streams. The strongest influence on the flue gas composition changes are the flow rates of coal, raw material and tertiary air stream have [26].

Maintaining a constant coal flow rate in the calciner can increase the amount of air entering the calciner which will result in a decrease in the reductive $\mathrm{NO}, \mathrm{CO}$, and $\mathrm{SO}_{2}$ concentrations. Furthermore, the concentration of $\mathrm{CO}_{2}$ in the flue gas decreases with increasing flow rate of coal and tertiary air, but this has no effect on the decomposition rate of the feedstock [23]. Under operating conditions (temperature $1100^{\circ} \mathrm{C}$ and pressure $20 \mathrm{~atm}$ ) of calciner, an ash content for CPC is decrease $0.25 \%$ and an increase in fixed carbon which reaches $99.3 \%$. The changes of proximate and ultimate data analysis on GPC and CPC in the simulation process can be seen in table 6 . Decreasing of ash content and volatile matter in GPC lead the characteristics of GPC Indonesian industries to meet industry standards to be processed into $\mathrm{CPC}$ as raw material for anode manufacture.

Table 6. The proximate and ultimate analysis using software simulation

\begin{tabular}{|l|c|c|c|c|}
\hline $\begin{array}{c}\text { Compo- } \\
\text { nents }\end{array}$ & $\begin{array}{c}\text { Temp } \\
\left({ }^{\circ} \mathrm{C}\right)\end{array}$ & $\begin{array}{c}\text { Press } \\
(\mathrm{atm})\end{array}$ & $\begin{array}{c}\text { Mass } \\
\text { Flow } \\
(\mathrm{kg} / \mathrm{hr})\end{array}$ & $\begin{array}{c}\text { Entalphy } \\
(\mathrm{cal} / \mathrm{sec})\end{array}$ \\
\hline $\begin{array}{l}\text { GPC to } \\
\text { calciner }\end{array}$ & 15 & 1 & 1167,95 & $-0,0712$ \\
\hline $\begin{array}{l}\mathrm{O}_{2} \text { to cal- } \\
\text { ciner }\end{array}$ & 25 & 1 & 439,00 & $\begin{array}{c}- \\
111,7042\end{array}$ \\
\hline $\begin{array}{l}\mathrm{CPC} \\
\text { from cal- } \\
\text { ciner }\end{array}$ & 1100 & 20 & 1606,95 & 279,1364 \\
\hline $\begin{array}{l}\mathrm{CPC} \\
\text { from gas- } \\
\text { ifier }\end{array}$ & 1100 & 1 & 438,03 & 313,4068 \\
\hline $\begin{array}{l}\mathrm{CO}{ }_{2} \text { from } \\
\text { gasifier }\end{array}$ & 1100 & 1 & 1168,92 & 266,2943 \\
\hline $\begin{array}{l}\text { GPC to } \\
\text { calciner }\end{array}$ & 15 & 1 & 1167,95 & $-0,07123$ \\
\hline $\begin{array}{l}\mathrm{O}_{2} \text { to cal- } \\
\text { ciner }\end{array}$ & 25 & 1 & 439,00 & - \\
\hline
\end{tabular}

\section{CONCLUSION}

The manufacture of calcinated coke using a shaft kiln is more flexible in the heating process for green petroleum coke raw materials and excess air. Green Petroleum coke specifications have high ash, volatile matter and moisture 
content, while low fixed carbon. To obtain industrial specifications, simulations were carried out using Aspen Plus. Aspen plus simulation helps determine the content of calcined petroleum coke by providing a modified calciner with a gasifier to reduce ash content followed by moisture and volatile matter.

\section{REFERENCES}

[1] Sarkar A, Kocaefe D, Kocaefe Y, Sarkar D, Bhattacharyay D, Morais B and Chabot J 2014 Coke-pitch interactions during anode preparation Fuel 117 pp 598-607.

[2] Rohani A, Sharifi K and Golpasha R 2014Calcinations of petroleum coke 3rd InternationalConference on Chemical, Ecology and Environmental Sciences (Abu Dhabi)

[3] Birghila S, Popovici I C, and Dumitru A 2011 Study on physical-chemical properties of petroleum cokes Romanian Journal of Physics 56 pp 976-82

[4] Edward L 2014 The history and future challenges of calcined petroleum coke production and use in aluminum smelting JOM 67 pp 308-321

[5] Santos, Ramos A, Silva da R J and Renó M L G 2015 Analysis of petroleum coke consumption in some industrial sectors Journal of Petroleum Science Research.

[6] Lee W J, Kim D Y, Choi J H, Lee J W, Kim J S, Son K, and Kang J 2019 Utilization of petroleum coke soot as energy storage material Energies $12 \mathrm{p}$ 3195

[7] Martins M A, Oliveira L S and Franca AS 2001 Modeling and simulation of petroleum cokecalcination in rotary kilns Fuel 80 pp 1611-1622

[8] Tang X B, Ma C X, Liu Q Y, Li G D and Liu Z Y 2010 Reactions of calcium compounds and coke for preparation of calcium carbide Fuel Chem. and Tech. 38 pp 539-543.

[9] Dourson M L, Chinkin L R, MacIntosh D L, Finn J A,Brown K W, Reid S B and Martinez J M2016 A case study of potential human health impacts from petroleum coke transfer facilitiesAir \& Waste Management Association 66 pp1061-76

[10] Wulandari W, Mursito A T, Juanjaya F J and Alwi M F 2018 Performance of dolomite calcination in a bench-scale rotary kiln MATEC Web of Conferences 156 p 06008 (Indonesia: EDP Sciences)

[11] Edwards L 2020 Carbon anode raw materials Light Metals pp 1163-65

[12] Janerka, K, Kondracki M, Jezierski J, Szajnar J and Stawarz M 2014 Carburizer effect on castiron solidification Materials Engineering and Performance 23 pp 2174-81
[13] Keller F and Sulger PO 2008 Anode Baking 2 (Sierre: R\&D Carbon Ltd)

[14] Camilla S, Rebecca J T, Arne P R, Rspen S, Hogne L, Lorentz P L and Ann M S 2017 The effect of varying mixing temperatures and baking level on the quality of pilot-scale anodes - a factorial design analysis Metals (Basel) 7 pp 1-12

[15] Edwards L, Vogt F, Robinette M, Love R, Ross A, Mc Clung M, Roush R Jand Morgan W 2009Use of shot coke as an anode raw material TMS Light Met. pp 985-990

[16] J. M. Lee, J. J. Baker, J. G. Rolle, and R. Llerena 1998 Characterization of green and calcined coke properties used for aluminum anode-grade carbon ACS Div. Fuel Chem. Prepr. 43 pp 271-5

[17] Anthony A and Richard K L 2013 Petroleum coke: Industry and environmental issues U.S. Pet. Refine. Petcoke Issues, Small Refine. Oppor. Ind. Backgr. pp 1-30

[18] Edward L 2011 Quality And Process Performance Of Rotary Kilns And Shaft Calciners Edited by: Stephen J L (USA: TMS (The Minerals, Metals \& Materials Society)

[19] Ellis P J and Paul C A 2000 Tutorial: Petroleum coke calcining and the uses of calcined petroleum coke 3rd International Conference on Refining Processing: Topical Conference Proceedings pp 86112

[20] Ulrich M, Werner K F, Raymond P and Age de V Profitable calcining of non-calcinable petroleum coke pp 1-4

[21] Yi S, Haifei X, Yubin W, Yinhe C and Chaodong 2010 Comparison between vertical shaft furnace and rotary kiln for petroleum coke calcination

[22] F. Becker and F. Goede 2006 Ring pit furnaces for baking of high-quality anodes - an overview Alum. Int. J. pp 1-15

[23] Zhang Y, Cao S X, Shao S, Chen Y, Liu S L and Zhang S S 2011 Aspen plus-based simulation of a cement calciner and optimization analysis of air pollutants emission Clean Technol.Environ. Policy 133 pp 459-468

[24] Hoffman Z 2003 Simulation and economic evaluation of coal gasification with sets reforming process for power production (Louisiana State University: LSU Digital Common)

[25] Jinsheng W, Edward J A and Juan C A 2004 Clean and efficient use of petroleum coke for combustion and power generation Fuel 83 pp 1341-48

[26] Mujumdar K S, Ranade V V 2006 Simulation of rotary cement kilns using a one-dimensional model Chem Eng Res Des 84(A3) pp 165-177 